\title{
ANALISIS KEGAGALAN MATERIAL KOPLING MESIN SLITTING DI PT. XYZ
}

\author{
Jatira $^{1}$, Amri Abdulah², Muhamad Wisnu Purnama ${ }^{3}$, Renaldi ${ }^{4}$ \\ 1,2,3,4,Program Studi Teknik Mesin, Sekolah Tinggi Teknologi Wastukancana
}

\begin{abstract}
Abstrak
Kopling merupakan salah satu komponen mesin slitting yang berfungsi untuk memutuskan dan menghubungkan putaran daya mesin ke unit pemindah tenaga atau transmisi dengan tujuan mengubah kecepatan sesuai yang diinginkan. Adapun permasalahan yang diakibatkan kopling ialah kegagalan patah pada kopling. Untuk mengetahui permasalahan kegagalan patah pada kopling ada beberapa pengujian yang dilakukan, diantaranya dengan pengujian spektrometer, pengujian kekerasan dan pengujian metalografi. Pengujian dilakukan untuk mengetahui nilai kekerasan pada material kopling akibat pembebanan yang terjadi pada kopling. Pengujian dilakukan dengan membandingkan material kopling dengan material S45C menggunakan metode heat treatment dengan variasi media pendingin. Hasil dari penelitian yang dilakukan menunjukan bahwa terdapat perbedaan nilai kekerasan antara material kopling dengan material S45C, dimana hasil pengujian material kopling menghasilkan nilai kekerasan rata-rata $97 \mathrm{HRB}$ sedangkan pada material S45C menghasilkan nilai kekerasan ratarata $88,9 \mathrm{HRB}$, berdasarkan perubahan fasa ferrite, pearlite dan martensite hasil pengamatan metalografi.
\end{abstract}

Kata kunci : Kopling, kegagalan, kekerasan, metalografi, S45C

\section{Pendahuluan}

Seiring dengan banyaknya kegagalan mekanis yang ditemui, perkembangan ilmu pengetahuan dan banyaknya penemuan baru, menyebabkan faktorfaktor perancangan mulai bertambah. Salah satu contohnya misalnya faktor kelelahan logam. Pada saat ini faktor kelelahan belum diketahui, perencanaan suatu komponen hanya didasarkan pada pembebanan statik. Namun dalam aktualnya masih ditemukan banyak masalah seperti patahnya kopling mesin slitting yang mengakibatkan terhambatnya proses produksi sehingga berdampak pada kerugian perusahaan. Oleh karena itu untuk mengetahui seberapa besar pengaruh beban-beban tersebut terhadap kekuatan lelah material kopling, maka diperlukan pengujian material menggunakan benda uji (spesimen) dan disertai dengan analisa maupun perhitungan secara teliti.

Dalam pengujian lelah/fatigue dipengaruhi oleh beberapa faktor yaitu konsentrasi tegangan, kondisi permukaan, dimensi, temperatur, beban dan efek lainlain (korosi). Pada suatu poros berputar/bekerjanya adalah untuk menghasilkan daya dorong, poros tersebut menanggung berbagai jenis beban akibat dari kombinasi berbagai bentuk gaya. Beban yang terjadi pada waktu berputarnya / bekerjanya poros adalah beban puntir, beban lentur putar, beban tekan dan beban tarik, dimana beban-beban tersebut terjadi secara berulang-berulang yang akhirnya akan terjadi kegagalan lelah (fatigue failure) pada material. Oleh karena itu penggunaan material untuk sebuah kopling harus memenuhi standar tertentu.

Mesin slitting secara umum berfungsi merapihkan (menyusun kain dalam roda) ketika kain turun dari dyeing c, kondisi kain tidak beraturan (terlilit) setelah masuk slitting / di proses di mesin slitting kain dalam keadaan tersusun rapi di roda, didalam kontruksi mesin ini terdapat kopling yang berfungsi meneruskan putaran pada saat berjalan nya mesin, di bagian kopling ini sering terjadi keausan, korosi dan sampai mengalami patah.

Oleh karena itu dibutuhkan suatu metode yang bertujuan untuk mencari kegagalan yang terjadi pada kopling mesin slitting sehingga di dapat material yang sesuai untuk digunakan pada kopling mesin slitting.

\section{Kajian Pustaka}

\subsection{Mesin Slitting}

Mesin slitting merupakan mesin produksi di perusahaan PT XYZ berperan penting dalam proses produksi seperti ditunjukkan pada gambar 1 .

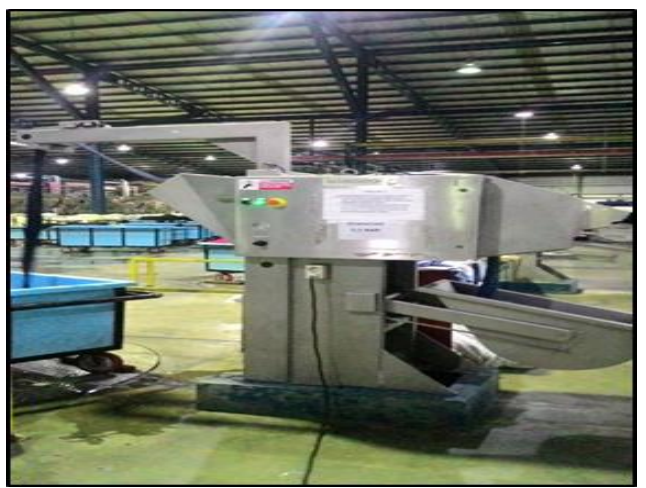

Gambar 1. Kain masuk proses mini manggle

Mesin slitting merupakan gerbang pertama menuju departemen finishing, setelah kain turun dari mesin dyeing (pemberian warna) maka kain akan proses oleh mesin slitting. Ada dua jenis kain yang turun dari dyeing, yang pertama kain berprofil bulat 
dan yang kedua kain sudah terbelah (tidak bulat), kondisi kain pada saat itu tidak beraturan.

Pada gambar 2.1 menunjukan proses masuknya kain ke mesin slitting (tepatnya di mini mangle) setelah mengalami proses di mesin dyeing. Fungsi utama mesin slitting ialah merapihkan kain yang akan kemudian di lanjutkan ke mesin stenter untuk proses pengeringan, fungsi mesin-mesin slitting yaitu :

a. Merapihkan kain yang sebelumnya tidak beraturan.

b. Mengurangi kandungan air dalam kain dengan cara pengepresan manggle (squeezing rolls), satu manggle sebelum pembilasan dan satu manggle setelahn pembilasan.

c. Pembilasan, dengan sistem air mengalir.

d. Membelah kain (jika kain berprofil bulat).

\subsection{Kopling}

Kopling terletak diantara engine dan transmisi yaitu suatu unit untuk penggerakan atau sistem yang merupakan dari sistem pemindah daya dengan fungsi untuk memutuskan dan menghubungkan putaran daya mesin ke unit pemindah tenaga.

\section{Fungsi kopling}

Fungsi kopling adalah untuk memindahakan tenaga mesin ke transmisi, kemudian transmisi mengubah tingkat kecepatan sesuai yang diinginkan, kopling dikatakan baik jika memiliki syarat sebagai berikut :

a. Dapat menghubungkan putaran mesin ke transmisi dengan lembut.

b. Dapat memindahakan tenaga mesin ke transmisi tanpa slip.

c. Dapat memutuskan hubungan denagan sempurna.

\section{Jenis-jenis kopling}

Secara garis besar dapat di kelompokan menjadi dua yaitu : kopling tetap dan kopling tidak tetap

\section{A. Kopling Tetap}

Kopling tetap adalah suatu elemen mesin yang berfungsi sebagai penerus putaran dan dari daya poros penggerak ke poros yang digerakan secara pasti (tanpa slip), dimana kedua sumbu poros tersebut terletak pada suatu garis lurus atau berbeda sumbunya "kopling tetap selalu dalam keadaan terpasang, untuk memisahkannya harus dilakukan pembongkaran.

Macam-macam kopling tetap

a. Kopling fluida

b. Kopling kaku

c. Kopling karet ban

B. Kopling tidak tetap

Kopling tidak tetap adalah suatu elemen mesin yang menghubungkan poros penggerak ke poros yang digerakan dengan putaran yang sama dalam meneruskan daya, serta dapat melepaskan hubungan kedua poros tersebut baik dalam keadaan diam maupun berputar. Kopling tidak tetap digunakan menyambung poros-poros dengan tujuan :

a. Digunakan untuk menyambung poros-poros dari unit yang dibuat terpisah dan juga digunakan untuk melepas guna perbaikan atau pergantian motor atau generator.

b. Digunakan untuk ketidak sejajaran dari poros atau untuk membuat fleksibilitas mekanis.

c. Mengurangi transmisi dari beban kejut dari satu poros ke lainnya.

d. Untuk melindungi perlindungan terhadap beban lebih.

e. Untuk mengubah karakteristik getaran unit yang berputar.

Macam-macam kopling tidak tetap :

a. Kopling cakar

b. Kopling plat

c. Kopling kerucut

d. Kopling friwil

\subsection{Definisi baja}

Pada masa awal penggunaanya sekitar tahun 4000 SM, besi (komponen utama penyusun baja) digunkan untuk membuat peralatan-peralatan sederhana. Material ini dibuat dalam bentuk besi tempa yang diperoleh dengan memanaskan bijih-bijih besi dengan menggunakan arang. Pada abad ke-19 muncul matrial baru dinamakan baja yang merupakan logam paduan antara besi dan karbon. Material baja mengandung kadar karbon yang lebih sedikit dari pada besi tuang, dan mulai digunakan dalam konstruksi-konstruksi berat. Sir Henry menerima hak paten dari pemerintah Inggris pada tahun 1855 atas temuannya tersebut. Beliau mempelajari bahwa dengan menghembuskan aliran udara di atas besi cair panas akan membakar kotoran-kotoran yang ada dalam besi tersebut, namun secara bersamaan proses ini juga menghilangkan komponen-kornponen penting seperti karbon dan mangan. Selanjutnya komponen-komponen penting ini dapat digantikan dengan suatu logam paduan antara besi, karbon dan mangan, di samping itu juga mulai ditambahkan batu kapur yang dapat mengikat senyawa fosfor dan sulfur. Dengan ditemukannya proses Bessemer, maka di tahun 1870 baja karbon mulai dapat diproduksi dalam skala besar dan secara perlahan material baja mulai menggantikan besi tuang sebagai elemen konstruksi. Baja yang akan digunakan dalam struktur dapat diklasifikasikan menjadi baja karbon, baja paduan rendah muru tinggi, dan baja paduan.

\section{Baja karbon}

Baja karbon dibagi menjadi 3 kategori tergantung dari persentase kandungan karbonya, yaitu:

a. baja karbon rendah $(\mathrm{C}=0,03-0,35 \%)$

b. baja karbon medium $(\mathrm{C}=0,35-0,50 \%)$

c. baja karbon tinggi $(\mathrm{C}=0,55-1,70 \%)$

Baja yang sering digunakan dalam struktur adalah baja karbon medium misalnya baja ST 37. 
Kandungan karbon baja medium bervariasi dari 0,25$0,29 \%$ tergantung ketebalan. Selain karbon, unsur lain juga terdapat dalam baja karbon adalah mangan $(0,25-1,50 \%)$, silicon $(0,25-0,30 \%)$, fosfor (maksimal $0,04 \%)$ dan sulfur $(0,05 \%)$. Baja karbon menunjukan titik peralihan leleh yang jelas, baja karbon umumnya memiliki regangan leleh $(f)$ antara 210-250 MPa.

\section{Baja paduan}

Baja paduan rendah (low alloy) dapat ditempa dan di panaskan untuk memperoleh tegangan antara 550-760 MPa. Tegangan leleh dari baja paduan biasaya ditentukan sebagai tegangan yang terjadi saat timbul tegangan permanen sebesar $0,2 \%$, atau dapat ditentukan pula sebagai tegangan pada saat regangan mencapai $0,5 \%$.

Unsur-unsur paduan logam diantaranya yaitu:

A. Belerang (S) dan Fosfor (P)

Unsur-unsur ini lebih sebagai kotoran yang terbawa bijih besi dari pada sebagai paduan. Kandungan belerang dan fosfor harus dibuat sedikit mungkin, karena mempengaruhi kualitas baja. Dalam jumlah yang banyak belerang dapat menjadikan baja rapuh dalam keadaan panas, sedangkan fosfor dapat menjadikan baja rapuh dalam keadaan dingin.

B. Mangan (Mn)

Semua baja mengandung mangan karena sangat diperlukan dalam proses pembuatan baja. Kandungan mangan kurang lebih $0,6 \%$ masih belum bisa sebagai paduan dan tidak terpengaruhi sifat baja. Dengan bertambahnya kandungan Mn, suhu kritis diturunkan seimbang. Baja dengan $12 \% \mathrm{Mn}$ adalah austenit, karena itu suhu kritisnya dibawah suhu kamar, akibatnya baja tidak dapat diperkeras.

C. Nikel (N)

Nikel mempunyai pengaruh yang sama seperti mangan, yaitu menurunkan suhu kritis dan kecepatan pendingin kritis, memperbaiki kekuatan tarik, tahan korosi sifat tahan panas dan magnetnya. Nikel tahan korosi berkat lapisan kuat oksida nikel maka nikel digunakan untuk menutup logam-loagam lain. Dari paduan nikel kita sebut monel dan nikrom. Monel adalah paduan nikel dengan tembaga yang sedikit digunakan dalam mesin. Nikrom adalah paduan nikel dan krom yang digunakan untuk teknik listrik sebagai bahan hambatan.

D. Silikon $(\mathrm{Si})$

Silikon merupakan unsur paduan yang ada pada setiap baja dengan jumlah kandungan lebih dari 0,4\% yang mempunyai pengaruh menaikan tegangan tarik dan menurunkan kecepatan pendingin kritis.

\section{E. $\operatorname{Kromium}(\mathrm{Cr})$}

Kromium menambah kekuatan tarik dan keplastisan, menambah maupun keras, meningkatkan ketahanan terhadap korosi dan tahan suhu tinggi.

F. Tungsten (W), Molibden (Mo), Vanadium (V)

Unsur-unsur tersebut membentuk karbid yang sangat keras dan memberikan baja kekerasan tinggi, kemampuan potong dan daya tahan panas yang cukup tinggi pada yang sangat diperluakan untuk pahat potong dengan kecepatan tinggi.

\subsection{Struktur mikro baja}

\section{A. Ferrite}

Ferrite adalah fasa larutan pada logam Fe yang memiliki struktur Kristal body centered cubic dengan sifat lunak dan ulet. Pada temperature ruang kelarutan karbon dalam fasa ferrite hanya $0,008 \% \mathrm{C}$, dan pada temperature $723 \mathrm{oC}$, kelarutan karbon maksimal yaitu $0,025 \% \mathrm{C}$, lebih kecil dibandingkan dengan kelarutan karbon di dalam fasa larutan padat lain di dalam baja. B. Austenite

Austenite adalah interstitial padat dari karbon terlarut pada gamma $(\gamma)$ area yang memiliki struktur atom face centered cubic. Fasa austenite $(\gamma)$ ditentukan dalam keadaan setimbang bersifat non magnetic dan ulet pada temperature tinggi. Kelarutan atom karbon dalam larutan padat austenite lebih besar jika dibandingkan dengan kelarutan atom karbon pada fasa ferrite yaitu sebesar $2 \%$ pada temperature $1.130 \mathrm{oC}$

C. Cementit (Fe3C)

Cementit (Fe3C) adalah senyawa yang terdiri dari besi dengan karbon yang secara umum dikenal karbida besi dengan kelarutan karbon sebesar 6,67\%C dan 93,33\% Fe. Secara mekanik Cementit (Fe3C) mempunyai sifat kekutan tarik yang rendah dan kekutan tekan yang tinggi serta sifat kekerasan dengan harga kekerasan antara 65-68 HRC, namun kelemahannya adalah getas dan rapuh karena kandungan karbon yang tinggi pada struktur Cementit (Fe3C) sel satuan yang terbentuk adalah orthorhombic.

D. Pearlite $(\alpha+\mathrm{Fe} 3 \mathrm{C})$

Pearlite $(\alpha+$ Fe3C) adalah campuran ferrite $(\alpha)$ dan Cementit yang memiliki kekerasan sekitar 10-30 HRC. Jika baja eutectoid $(0,8 \% \mathrm{C})$ diaustenisasi dan didinginkan dengan cepat ke temperature dibawah A1 misal $(500 \mathrm{oC})$ dan di biarkan temperature tersebut sehingga terjadi transformasi isothermal, maka austenite akan mengurai dan membentuk pearlite melalui proses (nukleasi) dan pertumbuhan. Pearlite terbentuk berupa campuran ferrite dan Cementite yang tampak seperti lempengan pipih.

\section{E. Bainite}

Bainite adalah fasa menstabil yang di peroleh dari fasa austenite menuju temperature yang lebih rendah dari temperature transformasi pearlite dan lebih tinggi dari temperature transformasi martensite. Sebagai contoh bila baja eutectoid $(0,8 \% \mathrm{C})$ dipanaskan hingga temperature austenite, lalu di dinginkan dengan cepat hingga temperature antara $250 \mathrm{oC}$ 450 oC dan ditahan pada temperature tersebut, maka hasil transformasinya berupa stuktur Bainite yang mempunyai kekerasan antara 45 HRC - 55 HRC.

\section{F. Martensite}

Martensite adalah larutan padat dari karbon lewat jenuh pada besi alfa sehingga sel-sel satunya terdistorsi. Struktur martensite diperoleh jika baja 
dari temperature austenite didinginkan sangat cepat misalnya proses quenching dengan menggunakan media air. Martensite tergolong kedalam bentuk struktur kristal body centered tetranpinigonal. Martensite tidak terjadi proses difusi, hal ini dikarenakan terjadinya pergerakan atom secara serentak dalm waktu yang sangat cepat sehingga atom yang tertinggal pada saat terjadi pergeseran akan tetap berada pada larutan padat. Baja yang berada pada fasa martensite akan memiliki sifat yang kuat dan keras hingga $65 \mathrm{HRC}$, akan tetapi juga bersifat getas dan rapuh.

\subsection{Pengujian Material}

1. Uji spektrometer

Uji spektrometer adalah untuk mengetahui unsur kimia atau penetuan kandungan pada logam dan non logam serta struktur mikro yang terdapat pada suatu material guna mengetahui sifat-sifat mekanik dan mikrostrukturnya. Spektrometer merupakan alat yang digunakan untuk mengukur absorbansi dengan cara melewatkan cahaya dengan panjang gelombang tertentu pada suatu objek kaca atau kuarsa yang disebut kuvet. Sebagian dari cahaya tersebut akan diserap dan sisanya akan dilewatkan. Nilai absorbansi dari cahaya yang dilewatkan akan sebanding dengan kosentrasi larutan di dalam kuvet.

2. Uji kekerasan

Kekerasan suatu material menyatakan kemampuan material tersebut untuk menahan deformasi plastis. Kekerasan didefinisikan sebagai ukuran kemudahan dan kuantitas khusus yang menunjukan sesuatu mengenai kekuatan dan perlakuan panas dari suatu logam, ketahanan logam terhadap penetrasi pada permukaanya dapat di perkirakan bahwa terdapat hubungan antara kekerasan dan kekuatan bahan. Terdapat 3 jenis umum mengenai kekerasan :

1. kekerasan goresan, (scratch hardness)

2. kekerasan lekukan (identation hardness)

3. kekerasan pantulan (rebound)

4. kekerasan dinamik (dynamic hardness)

\section{A. Uji kekerasan Brinnell}

Uji kekerasan Brinnell berupa pembentukan lekukan pada permukaan logam dengan menggunakan bola baja berdiameter $10 \mathrm{~mm}$ dan diberi beban $3000 \mathrm{~kg}$, untuk logam lunak beban dikurangi hingga tinggal $500 \mathrm{~kg}$, untuk menghindarkan jejak yang dalam dan untuk bahan yang sanagat keras digunkan paduan karbida tungsten dengan tujuan untuk memperkecil terjadinya distorsi identor.

Beban diterapkan selama waktu tertentu, biasanya 30 detik, dan diameter lekukan diukur dengan mikroskop daya rendah setelah beban tersebut dihilangkan. Kemudian dicari harga rata-rata dari 2 buah pengukuran diameter pada jejak yang berarah tegak lurus. Permukaan dimana lekukan akan dibuat harus relatif halus, bebas dari debu atau kerak. Angka kekerasan brinnell (BHN)[3] dinyatakan sebagai beban luas permukaan lekukan

\section{B. Uji kekerasan Vickers}

Uji kekerasan Vickers menggunakan penumbuk piramida intan yang dasarnya berbentuk bujur sangkar. Besarnya antara sudut permukaanpermukaan piramida yang saling berhadapan adalah 136o. Karena bentuk penumbuknya piramida, maka pengujian ini sering dinamakan uji kekerasan piramida intan. Angka kekerasan Vickers (VHN)[5] didefinisikan sebagai beban dibagi luas permukaan lekukan. Pada praktek luas ini dihitung dari pengukuranya mikroskop panjang diagonal jejak.

\section{Uji kekerasan rockwell}

Uji kekerasan rockwell mampu untuk membedakan perbedaan kekerasan yang kecil pada baja yang diperkeras dan ukuran lekukannya kecil, sehingga bagian yang mendapat perlakuan panas yang lengkap dapat diuji kekerasanya tanpa menimbulkan kerusakan. Uji ini menggunakan kedalaman lekukan pada beban-yang konstan sebagai ukuran kekerasan. Mula-mula diterapkan beban kecil (beban minor)sebesar $10 \mathrm{~kg}$ untuk menempatkan benda uji. Kemudian di terapkan beban yang besar (beban mayor), dan secara otomatis kedalaman lekukan akan tertekan oleh gauge petunjuk yang menyatakan angka kekerasan. Untuk indentornya biasanya digunakan penumbuk berupa kerucut intan 120o dengan puncak yang hampir bulat dan dinamakan penumbuk Brale, serta bola baja berdiameter 1/16 inchi dan 1/8 inchi. Beban besar yang digunakan adalah 60, 100 dan $150 \mathrm{~kg}$.

\section{Uji Metalografi}

Mikroskop cahaya pada semua cabang metalurgi fisik kegunaan mikroskop amat besar. Yang amat sederhana dalah mikroskop cahaya yang terdiri dari 3 bagian pokok:

a. lensa pemantul (illuminator), untuk memantulkan permukaan logam

b. lensa obyektif, yang mempunnyai daya pisah

c. lensa mata (eyepiece), untuk memperbesar bayanngan ynagn terbentuk oleh lensa obyektif.

Pengujian mikroskopik dari suatu benda uji yang mewakili suatu logam setelah pemolesan dan kemudian dietsa dengan bantuan larutan kimia yang sesuai dapat memberikan banyak gambaran seperti keteraturan dan ukuran butir, distribusi fasa hasil deformasi plastik dan eksistensi pengotor dan cacatcacat. Proses kimia atau etsa permukaan, mula-mula memperlihatkan batas butir, tapi lebih lanjut etsa akan memperlihatkan bayangan yang berbeda antara satu butir yang lain, hal ini menunjukan bahwa larutan etsa tidak mengikis permukaan logam seluruhnya melainkan sepanjang bidang-bidang kristalografi tertentu. Bagian yang memiliki orientasi yang sama kemudian terdapat satu butir dan karena setiap butir memiliki orientasi yang berbeda dari butir -butir di 
sekitarnya, setiap butir akan memantulkan kelensa obyektif dan hasilnya akan timbul sinar, sementara di sekitarnya memantulkan semua sinar ke lain arah dan tampak gelap.

\section{METODE PENELITIAN}

\section{A. Persiapan}

Tahapan yang dilakukan dalam proses pengujian ini meliputi berbagai aspek yang tersusun secara teratur meliputi.

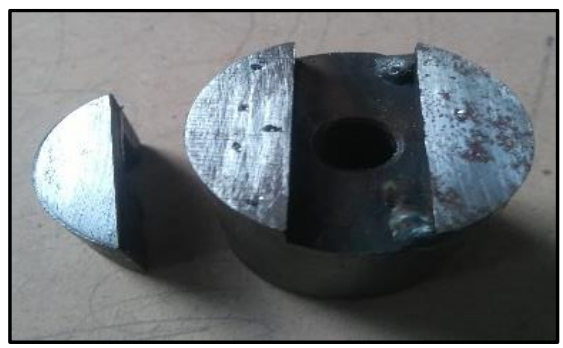

Gambar 2. Material kopling

Pada gambar 2. menunjukan material yang digunakan untuk pengujian yaitu raw material kopling mesin slitting dengan pengukuran material untuk spesimen uji dilakukan dengan standar ASTM

\section{B. Pemotongan}

Pemotongan material menggunakan mesin gerinda, untuk spesimen uji spektrometer 1 pcs, untuk spesimen uji kekerasan 1 pcs dan untuk spesimen uji metalografi 1 pcs selanjutnya dihaluskan spesimen uji, pada bagian yang telah dilakukan pemotongan menggunakan mesin gerinda datar.

\section{Pengujian Spektrometer}

Persiapan alat uji spektrometer yang akan digunakan pada spesimen uji. mesin pengujian yang digunakan pada spesimen uji ialah ARL 3460, dengan metode penembakan caiaran kimia pada material uji untuk mengetahui komposisi kandungan pada material uji.

\section{Pengujian kekerasan}

Pengujian kekerasan dilakukan menggunakan mesin rockwell, untuk mengetahui tingkat kekerasan pada spesimen uji. Tahapan Pelaksanaan Pengujian :

a. Memilih skala kekerasan yang akan dipakai sesuai spesimen uji.

b. Menghidupkan hidrolik (saklar on) pasang beban yang akan dibutuhkan.

c. Memasang identor yang sesuai dengan skala spesimen uji.

d. Menempatkan spesimen pada landasan mesin uji.

e. Mengatur skala kekerasan, dengan cara memutar tuas dari titik auto hingga set

f. Melakukan penekanan dengan beban awal (10 $\mathrm{kg}$ ) dengan cara menekan tuas pemutar satu kali, tunggu 5 sampai 10 detik. g. Melakukan penekanan dengan beban penuh, dengan cara menekan tuas pemutar satu kali lagi, tunggu sampai angka digital berhenti.

h. Mengamati kekerasan spesimen yang diuji dengan membaca nilai yang di tunjukan angka pada skala kekerasan.

\section{E. Pengujian Melografi}

Pengujian metalografi dilakukakan untuk mengetahui struktur mikro pada material kopling. Adapun tahapan yang harus dilakukan sebelum pengujian metalografi diantaranya sebagai berikut:

a. Cutting spesimen uji pada material kopling

b. Proses mounting dilakukan untuk mempermudah dalam memegang spesimen pada saat proses grinding dan polishing.

c. Grinding menghaluskan dan meratakan spesimen dengan menggunakan abrasive paper dari grit number 280, 400, 600, 800, 1000, 1200 dan terakhir grit number yang paling halus yaitu 1500.

d. Polishing, kemudian ganti abrasive paper, type $<6 \mu \mathrm{m}$ seperti kain beludru untuk proses polishing hingga permukaan mengkilap dan dan menghilangkan goresan bekas proses grinding dengan menggunakan pasta intan dan alumina.

e. Etching, melakukan etsa dengan menggunakan larutan asam nital (asam nitrit+alcohol $97 \%$ ) dan celupkan selama beberapa detik dan lihat secara kasat mata antara hardened zone dan soft region. Setelah selesai cuci spesimen dengan air diikuti alkohol dan keringkan terlebih dahulu sebelum proses selanjutnya.

f. Proses pengamatan metalografi

g. Pengamatan metalografi dilakukan untuk struktur mikro hasil pengujian spesimen uji.

\section{HASIL DAN PEMBAHASAN}

A. Hasil pengujian kekerasan Material Existing Hasil pengujian kekerasan dengan menggunakan rockwell pada material Existing dapat dilihat pada Tabel dibawah ini:

Tabel 1. Hasil Pengujian Spektrometer

\begin{tabular}{|l|l|l|l|}
\hline Material Uji & No & Unsur/Element & Nilai (\%) \\
\hline & 1 & Carbon (C) & 0,468 \\
\cline { 2 - 4 } & 2 & Silicon (Si) & 0,234 \\
\hline & 3 & Sulfur (S) & 0,007 \\
\hline & 4 & Phosphours (P) & 0,009 \\
\hline & 5 & Manganese (Mn) & 0,648 \\
\hline & 6 & Nickel (Ni) & 0,1 \\
\hline & 7 & Chromium (Cr) & 0,16 \\
\cline { 2 - 4 } & 8 & Molydenum (Mo) & 0,071 \\
\hline
\end{tabular}

Pada tabel 1. menunjukan hasil pengujian spektrometer material kopling mesin slitting dimana unsur karbon dengan nilai $0,468 \%$, silicon $0,234 \%$, 
sulfur 0,007 \%, phosphorus 0,009\%, manganese $0,648 \%$, nickel $0,10 \%$, chromium 0,16 , molydenum $0,071 \%$ sehingga dapat disimpulkan bahwa material tersebut adalah sama dengan baja karbon S45C.

\section{B. Hasil pengujian kekerasan Material S45C}

Hasil pengujian kekerasan dengan menggunakan rockwell pada material S45C dapat dilihat pada Tabel dibawah ini:

Tabel 2. Hasil pengujian kekerasan
\begin{tabular}{|l|c|c|}
\hline Pengujian & Nilai kekerasan \\
\hline No & HRB & HRC \\
\hline 1 & 98 & 55.4 \\
\hline 2 & 96 & 56.8 \\
\hline 3 & 97 & 58.2 \\
\hline 4 & 98 & 58.6 \\
\hline 5 & 96 & 58.1 \\
\hline Nilai Rata-rata & 97 & 57.42 \\
\hline Nilai Max & 98 & 58.2 \\
\hline Nilai Min & 96 & 55.4 \\
\hline R=max-min & 2 & 2.8 \\
\hline
\end{tabular}

Berdasarkan data yang diperoleh dari pengujian kekerasan, pada tabel 2. menunjukan bahwa nilai kekeresan pada material kopling dengan nilai maximum $98 \mathrm{HRB}$, minimum $96 \mathrm{HRB}$, rata-rata 97 HRB dan selisih maximum dan minimum adalah 2 HRB.

Berdasarkan data yang di peroleh dari hasil pengujian kekerasan brinell, secara grafik bervariatif, diantara nya nilai maximum 98 (HRB), nilai minimum 96 (HRB) rata-rata 97 (HRB) dan selisih antara maximum dan minimum adalah 2 (HRB). Sedangkan nilai (HRC) diantaranya nilai maximum 58,6 (HRC), nilai minimum 55,4 (HRC) rata-rata 57,42 (HRC) dan selisih antara maximum dan minimum adalah 2,8 (HRC).

\section{Perbandingan hasil pengujian dengan variasi media pendingin material $\mathrm{S45C}$}

Tabel 3. Hasil pengujian dengan variasi quenching

\begin{tabular}{|l|c|c|c|}
\hline \multirow{2}{*}{ Pengujian } & \multicolumn{3}{|c|}{ Media Quenching } \\
\cline { 2 - 4 } & Air & Air Kelapa & Oli \\
\cline { 2 - 4 } & \multicolumn{3}{|c|}{ Nilai HRC } \\
\hline 1 & 55.4 & 54.6 & 27.6 \\
\hline 2 & 56.8 & 53.6 & 26.5 \\
\hline 3 & 58.2 & 53.9 & 26.6 \\
\hline 4 & 58.6 & 53.2 & 26.4 \\
\hline 5 & 58.2 & 54.2 & 25.4 \\
\hline 6 & 57.4 & 53.9 & 26.4 \\
\hline Rata-rata & $\mathbf{5 7 . 4}$ & $\mathbf{5 3 . 9}$ & $\mathbf{2 6 . 5}$ \\
\hline Nilai Max & $\mathbf{5 8 . 6}$ & $\mathbf{5 4 . 6}$ & $\mathbf{2 7 . 6}$ \\
\hline Nilai Min & $\mathbf{5 5 . 4}$ & $\mathbf{5 3 . 2}$ & $\mathbf{2 5 . 4}$ \\
\hline R=max-min & $\mathbf{3 . 2}$ & $\mathbf{1 . 4}$ & $\mathbf{2 . 2}$ \\
\hline
\end{tabular}

Berdasarkan data yang diperoleh dari pengujian kekerasan, pada table 3 . menunjukan bahwa variasi media pendingin air, air kelapa dan oli dimana nilai kekerasan tertinggi ada pada air dan kekerasan terendah ada pada oli.

Pada Gambar 3. hasil pengamatan pada metalografi terlihat fasa pearlite dan ferrite pada material kopling mesin slitting.

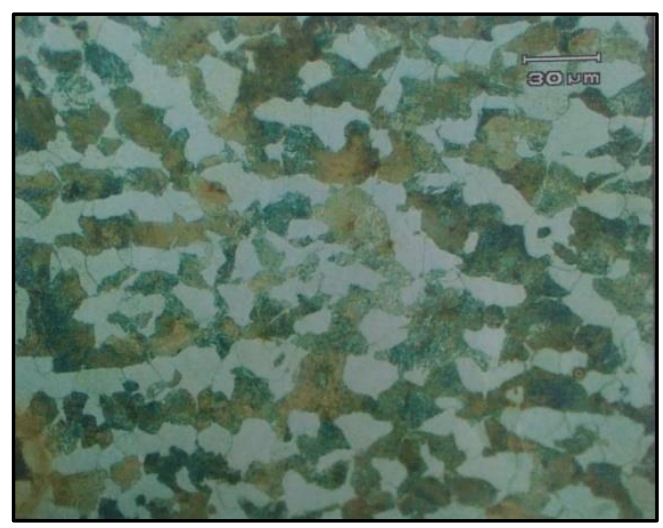

Gambar 3. Hasil pengamatan pada material existing kopling

Pada Gambar 4.a hasil pengamatan metalografi terlihat fasa martensit pada proses quenching dengan media pendingin air. Pada Gambar 4.b hasil pengamatan pada metalografi terlihat fasa martensit, pada proses quenching dengan media pendingin air kelapa. Pada Gambar 4.c hasil pengamatan pada metalografi terlihat fasa pearlite dan ferrite pada proses quenching dengan media pendingin oli.

Pada gambar 5.a. menunjukan berdasarkan data yang di peroleh dari hasil pengujian kekerasan rockwell skala A, secara grafik bervariatif, perbandingan antara media pendingin terhadap hasil uji kekerasan. Pada media air terjadi kenaikan kekerasan dari titik uji spesimen pada yang ke titik 1 hingga ke titik 4 dan terjadi penurun kekerasan dari pengujian ke titik 5 hingga ke titik 6 .

Pada gambar 5.b. menunkan grafik berdasarkan data yang di peroleh dari hasil pengujian kekerasan rockwell skala A, secara grafik bervariatif, perbandingan antara media pendingin terhadap hasil uji kekerasan. Pada media air kelapa terjadi penurunan kekerasan dari titik uji spesimen pada yang ke titik 1 hingga ke titik 4 dan terjadi kenaikan kekerasan dari pengujian ke titik 4 hingga ke titik 5 dan terjadi kenaikan dari titik 5 ke titik 6.

Pada gambar 5.c. menunjukan berdasarkan data yang di peroleh dari hasil pengujian kekerasan rockwell skala A, secara grafik bervariatif, perbandingan antara media pendingin terhadap hasil uji kekerasan. Pada media oli terjadi penurunan kekerasan dari titik uji spesimen pada yang ke titik 1 


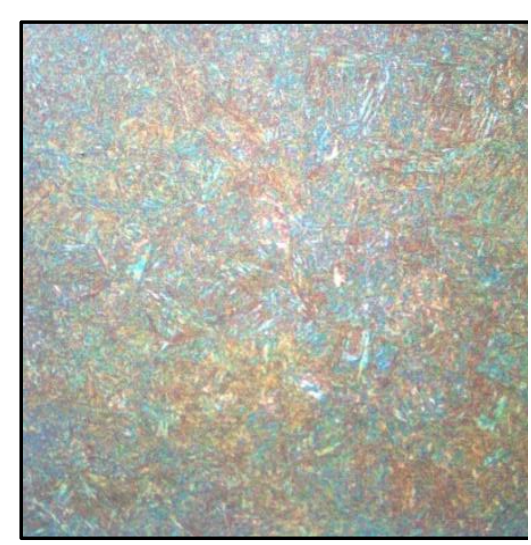

(a)

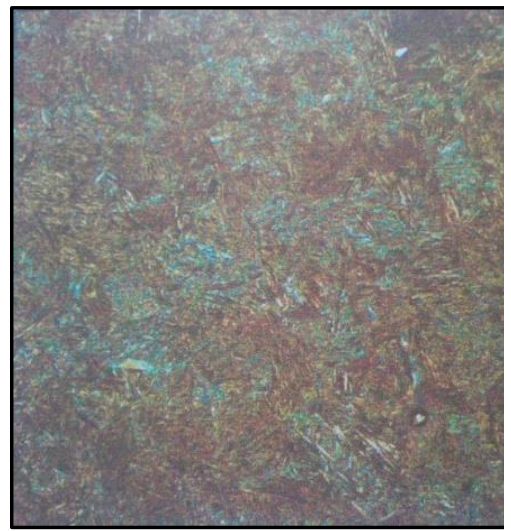

(b)

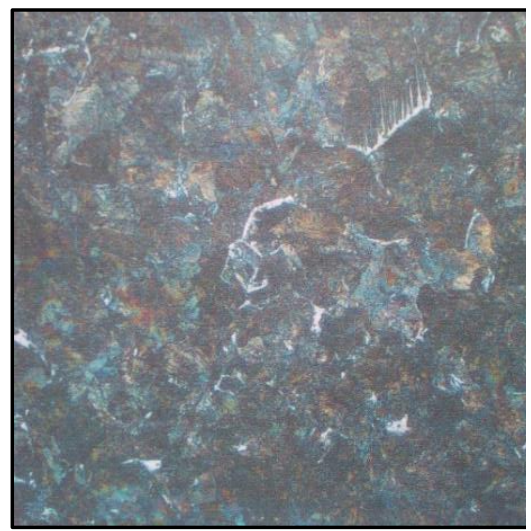

(c)

Gambar. 4. Hasil pengamatan metalografi

a. Media pendingin air b. Media pendingin air kelapa c. Media pendingin oli

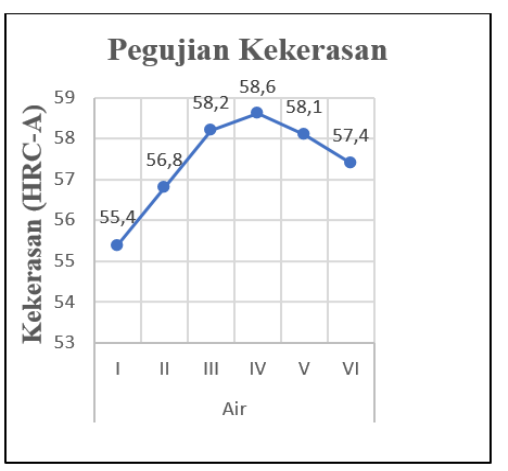

(a)

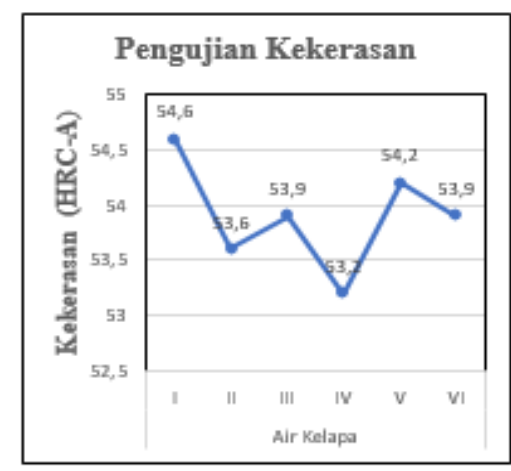

(b)

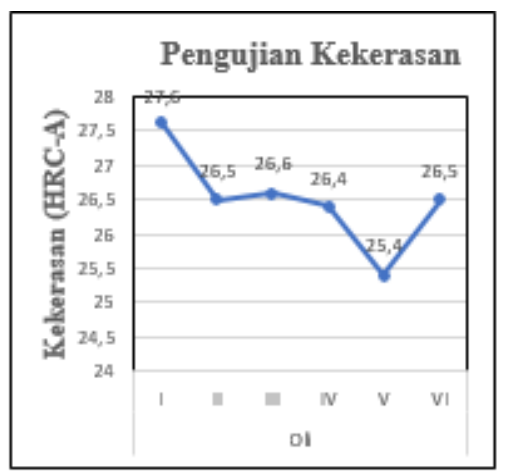

(c)

Gambar 5. Hasil pengujian kekerasan Rockwell

a. Media pendingin air b. Media pendingin air kelapa c. Media pendingin oli

Tabel 4. Struktur kimia pada baja ST 60

\begin{tabular}{|c|l|c|}
\hline \multicolumn{3}{|l|}{ Baja Karbon ST 60 } \\
\hline No & Nama Uns ur & Persentase (\%) wt) \\
\hline 1 & Besi (Fe) & 98,27 \\
\hline 2 & Nikel (Ni) & 0,0032 \\
\hline 3 & Mangan (Mn) & 0,7535 \\
\hline 4 & Krom (Cr) & 0,0248 \\
\hline 5 & Karbon (C) & 0,5486 \\
\hline 6 & Silikon (Si) & 0,3085 \\
\hline 7 & Molibdenum & 0,0018 \\
\hline 8 & Tembaga (Cu) & 0,0124 \\
\hline 9 & Alumunium (Al) & 0,0214 \\
\hline 10 & Belerang (S) & 0,0051 \\
\hline 11 & Seng (Zn) & 0,0147 \\
\hline 12 & Titanium (Ti) & 0,0124 \\
\hline 13 & Fospor (P) & 0,0315 \\
\hline 14 & Timbal (Pb) & 0,0051 \\
\hline 15 & Kalsium (Ca) & 0,002 \\
\hline
\end{tabular}

Pada table 4. menunjukan bahwa komposisi kimia yang ada pada material baja ST 60. Dari data analisa kegagalan dan serangkaian pengujian yang telah dilakukan maka dapat disimpulkan material S45C tidak cocok untuk material pembuatan kopling mesin slitting, maka dari itu disarankan untuk melakukan pengujian heat treatment atau menggunakan material lain yang lebih cocok dan sesuai seperti St 60 dimana memiki kadar karbon yang lebih tinggi serta ulet dari material S45C.

\section{KESIMPULAN}

Dari data hasil penelitian yang telah dilakukan, dapat disimpulkan bahwa analisa kegagalan kopling pada mesin slitting di PT. XYZ diantaranya : Material komponen kopling sesuai dengan standar JIS G4051 S45C untuk kategori Carbon Steels for Machine Stuctural Use. Kegagalan terjadi disebabkan oleh pembebanan yang berulang-ulang pada kopling sehingga terjadinya kelelahan (fatigue) pada bagian tengah material kopling. Tidak adanya proses heat treatment pada saat proses pembuatan material kopling mesin slitting membuat kurang kuatnya material saat menahan beban yang di terima sehingga diperlukannya perlakuan panas pada material. Terdapat perbedaan nilai kekerasan pada material kopling, dengan material S45C, dimana hasil pengujian material kopling menghasilkan nilai kekerasan rata-rata $97 \mathrm{HRB}$ sedangkan pada material S45C menghasilkan nilai kekerasan rata-rata 88,9 HRB. 


\section{DAFTAR PUSTAKA:}

[1] G. E. Dieter and S. Djaprie, Metalurgi Mekanik, Ketiga. Jakarta: Erlangga, 1990.

[2] D. . H. Armanto and D. Daryanto, "Ilmu Bahan.” PT Bumi Aksara, Jakarta, 1999.

[3] B. H. Amstead, P. F. Ostwald, and M. L. Begemen., Teknologi Mekanik, Ketujuh. Jakarta: Erlangga, 1997.

[4] R. E. Salman., "Metalurgi Fisik Modern.” PT Gramedia Pustaka Utama, Jakarta, 1991.

[5] L. Van Vlack and S. Djaprie, Ilmu dan Teknologi Bahan, Kelima. Jakarta: Erlangga, 1993.

[6] H. Sonawan and R. Suratman, "Pengantar Untuk Memahami Proses Pengelasan Logam." AlfaBeta, 2006.

[7] I. Sularso and MSME, Dasar Perancangan Dan Pemilihan Elemen Mesin, Ke Dua Bel. Jakarta: Pradnya Paramita.

[8] H. Sonawan, Perancangan Elemen Mesin, Ke Satu. Bandung: AlfaBeta, 2010.

[9] T. Marjuki and A. Fianel, Buku Tabel Teknik Mesin, Pertama. Malang: CV Gunung Samudera, 2013.

[10] H. Anrinal, Metalurgi Fisik. Yogyakarta: CV. Andi Offset, 2010.

[11] Yunaidi., "Pengaruh Jumlah Konsentrasi Larutan Garam Pada Proses Quenching Baja Karbon Sedang S45C.” 2016.

[12] T. Hidayat, P. Hartono, and Sujatmika, "Analisa Pengaruh Suhu Pada Media Pendingin Terhadap Sifat Mekanis (Kekerasan) Baja S45C Pada Proses Hardening," Tek. Mesin, Fak. Tek. Univ. Islam Malang, 2014.

[13] G. R. F. S, M. Firman, and M. A. S. .P., "Analisa Uji Kekerasan Pada Poros Baja ST 60 Dengan Media Pendingin Yang Berbeda," Tek. Mesin UNSIKA, 2016.

[14] E. Satyartini, "Optimalisasi Sifat-Sifat Mekanik Material S45C," Fak. Teknol. Ind. Univ. Atma Jaya Yogyakarta, 2013. 